\title{
Visibility, Framing and Importance: Images of the EU in Japan and South Korea
}

\author{
NATALIA CHABAN, \\ CHRISTIAN ELIAS SCHNEIDER AND RICHARD MALTHUS
}

\begin{abstract}
Addressing an under-researched theme of international images and perceptions of the EU, this paper scrutinizes the framings of the Union endorsed in the news media and expressed by the general public in the two East Asian OECD countries - Japan and South Korea. Conclusions indicate that the EU's importance and presence is often underestimated in the region, and frequently seen in terms of 'economic muscle' only. The empirical data comes from a trans-national comparative research project, sponsored by the Asia-Europe foundation (ASEF). The research framework is interdisciplinary, drawing resources from critical discourse analysis, media and image studies, EU scholarship and political science.
\end{abstract}

Keywords: Asia-Pacific, external perceptions, EU, news media, public opinion

\section{Introduction}

The process of European integration recently celebrated its fiftieth anniversary. Existence of the European Union (EU), a peaceful integrationist polity, became a potent example of how a previously warring continent managed to overcome internal hostilities and mistrust and become an international reference for successful regional construction. However, a very specific mode of its development-namely 'from crisis to crisis' (as labelled by a European visionary Jean Monnet cited in Duff 2006) - adds to the impression that the EU (as a concept) and European integration (as a process) remain unpopular, problematic and even irrelevant to many people inside and outside the Union's borders. This vision is seemingly solidified through the recent series of so-called 'integration crises', such as citizens' lukewarm reception of the EU's enlargement to the East and to the South, their reluctant reaction to the prospects of Turkey's EU membership, an increasingly hostile welcome to the new migrants, as well as the rejection of the Constitutional Treaty by the French and Dutch electorates in 2005 and the Irish rejection of the Lisbon Treaty in 
2008. The EU's ambiguous identity - neither a federal supra-state nor an international intergovernmental organization - adds to a cognitive confusion accompanying the EU's understanding within and outside its borders. This confusion is further aggravated by the Union's complicated decision-making process (happening on national, supranational and even regional levels) as well as the EU's 'communication deficit' (deficient ability of the Union to communicate to and with its citizens). Unsurprisingly, the EU, even after half a century of existence, still carries a label of 'un objet politique non-identifié' (Jacques Delors cited in Schmitter 1996: 1).

Yet, despite these identity turbulences, a recent US German Marshall Fund survey found that 90 percent of EU citizens would like the EU to play a more visible global role (Spondenberg 2007). The growing importance of the EU as an international actor was registered in public perceptions discovered in nine countries ${ }^{1}$ by the Bertelsmann Stiftung survey (Vucheva 2007). These internal and external calls for 'more EU in the world' could be explained by the Union's growing global presence - its huge size and population, a long line of candidates hoping to join the club, an impressive economic capacity and an increasing weight in the international political arena. The last aspect could be illustrated by the EU's assertive roles as an advocate and a trendsetter in the fields of democracy, human rights, and environmental protection, as well as a reputable negotiator in international 'hotspots' and the largest donor of developmental aid in the world. In recent decades the EU has become more visible in the area of 'hard' international actions - the Union has established its own troops, participated in a number of peacekeeping operations and is developing its own anti-terrorism strategy. These developments are relatively recent and consequently not extensive in scale, yet indicative in their existence. Finally, the EU's model of peaceful economic and political integration has become a powerful point of reference internationally. This emerging international identity of the EU (a concept widely discussed in relevant literature; see e.g. Holland 1995, 2005; Cederman 2001; H. Smith 2002; K. Smith 2002; Ortega 2004; Lucarelli 2006; Lucarelli and Manners 2006; Sjursen 2006) is claimed by Manners and Whitman (1998: 246) to 'commence conceptualising the global role of the European Union as being greater than the sum of its parts', a position shared by discussion in this paper.

In the light of these evolutions in the EU's profile, does the new integrating Europe matter to the rest of the world? What are international images and perceptions of the EU? Could external visions of the EU 
affect the internal images and perceptions of the Union undergoing 'identity crises' in the eyes of its own citizens? If yes, then how? It is indeed suggested that ordinary EU citizens actually do not care about EU external perceptions, as they do not affect an EU citizen's daily life. This study, however, hypothesizes that internal critical processing of both positive and negative external reactions may further what Wallström (2005) called a 'common narrative' of modern Europe. The external perceptions of the EU as an external communal actor, successful in its international endeavours and respected by its many international partners will feed back into EU citizens' feeling of pride, a sense of belonging and an appreciation of the integrated polity. Vice versa, as Holland (1999: 243) noted, if the EU is perceived by its citizens to be failing in foreign affairs, this image will inevitably negatively affect the legitimation of the internal integration processes. Lucarelli (2007) develops these ideas further stating that external perceptions, if systematically identified, analysed and reported to the Europeans, are seen as a crucial step in providing internal critical reflections on the EU, a new polity that is looking for approval and validation of its distinctly innovative integration process from its citizens. In this context, recognition of the EU's external successes and challenges by powerful and important counterparts around the globe is significant in particular.

With Asia being Europe's important Other, it is unsurprising that Europe is currently involved in what Bridges (1999: 199) called the 'reexploration' and 're-invention' of Asia. This is due, first and foremost, to Asia's booming economy and the reputation of Asian nations as 'energetic and competitive traders and ... investors' (Ibid.). In return, does the EU matter to Asia? This paper provides a pioneering systematic insight into the EU's visibility and framing in the Asian news media and compares those to the perceived importance held on the popular level in the two affluent countries - Japan and South Korea (hereafter referred to as Korea). Given Japan's and Korea's economic prowess and vibrant democratic societies (recognized by a membership in the OECD, an organization uniting the so-called 'developed' nations in the world), these states are able to significantly impact global and regional happenings, and thus compete with other world powers for influence. Predictably, these states will be watching vigilantly (if not jealously) for any other influences infiltrating 'their' region. In this context, the EU of 27 is critically scrutinized in the region, being a powerful economic player with a healthy common currency, a lucrative enlarging market and growing political aspirations. 
Since Asia and Europe are often conceptualized as ultimate Others to each other - consider Kipling's ubiquitous 'East is East, and West is West, and never the twain shall meet' - the intersections between the two are fruitful in the re-discovery of Self (either European or Asian); according to Hastings and Manning (2004: 293), 'identity is always constructed in relation to alterity'. However, this paper's inquiry into EU images and perceptions is argued to contribute not only to the highly contested debate on the so-called 'European identity', which often overlooks external dimensions (Stråth 2002). It also attempts to add to the scholarship of the EU's public diplomacy, identified by Hyde (cited in Kennedy and Lucas 2005) as efforts by a polity to 'communicate to, and engage with, foreign publics'. According to Lynch (2005: 15), research into foreign perceptions and attitudes (together with communication and information strategies, and cultural and educational actions) builds the core of this particular policy.

With the EU's public diplomacy currently lagging behind in the Union's policy-making process (Fiske de Gouveia and Plumridge 2005; Korski 2008), this paper aims to provide several useful insights into the state of external public opinion and media imagery of the EU in one particular global region - North East Asia. This paper's interest in public views on the EU on the background of the media framing of the Union is a novel perspective in the studies of EU external perceptions (which typically focus on elite images of the EU). This specific line of inquiry corresponds to the official views on the directions of the EU's public diplomacy - according to the European Commission's DG RELEX (2007), this policy deals with the 'influence of public attitudes' and singles out individual citizens and the media among the primary targets of its activities. Naturally, EU external policies cannot be shaped from public opinions alone, yet the successes and failures in the EU's 'PR campaign' in 'branding' itself with international publics do matter. According to Twigg (2005: vi):

[I]f the European Union is serious about taking a greater role in the world affairs it will require a public diplomacy capability to match. ... For the Union to prosper it must project a positive image of itself to opinion formers and to the 'man in the street' both within and beyond its borders.

\section{The EU and North East Asia}

According to a much debated vision of a globalizing world (see Sassen 1991; Castells 1996; Hirst and Thompson 1996; Petrella 1996; Brenner 1999; Katzenstein 2005), the EU (and wider Europe) joins the US/North 
America and the Asia-Pacific as one of the 'big three' in the triad of global centres of power. Even though the interactions between the three global 'giants' are ongoing and intensive, admittedly, the Europe-Asia link is still seen as the weakest one if compared with trans-Atlantic and trans-Pacific connections. History and cultural affinity are claimed to be crucial in the former case, whereas history and 'hard', war-and-peace politics are seen as the key in the latter. Encouragingly, the growing level of EU political involvement with Asia, on the back of ongoing and mutually profitable economic dialogue, has been registered in an impressive body of research (see Fukasaku et al. 1998; Maitland and $\mathrm{Hu}$ 1998; Bridges 1999; Dent 1999; Neves and Bridges 2000; Strange et al. 2000; Preston and Gilson 2001; Gilson 2002). ${ }^{2}$ While relevant literature focuses on economic and political interactions between Europe and Asia, it overlooks the flow of political communication between the two (including a systematic account of images and perceptions of each other). This paper aims to fill this scholarly gap. It focuses on one case-study: images and perceptions of the EU in two East Asian countries, Japan and Korea. East Asia is recognized here as an important counterpart to the EU within Asia as a whole region-indeed, as early as 1994 the European Commission's Communication 'Towards a New Asia Strategy' clearly outlined East Asia as one of three principle lines in the EU's dialogue with Asia (the two other lines being South East Asia/ASEAN and South Asia). Respectively, an account for images and perceptions of each other becomes an important element in meaningful interactions between the EU and East Asia.

The European Commission (EC External Relations online) recognized that 'Asia has recently surpassed NAFTA to become Europe's main trading partner, accounting for a third of Europe's total trade flows. Moreover, European FDI in Asia amounts to a third of European investment abroad, and is growing.' Unsurprisingly, the EU's interface with East Asian powers (including Japan and Korea) prioritizes economic aspects. Reciprocally, economic interactions with the EU-27 are vital for the economic 'health' of the whole region, including the two countries in this study. For example, in 2004 the EU was third in Japan's imports and ranked 'No. 2 ' in exports (EC Delegation to Japan online). Similarly, the EU has been Korea's third major international export partner (EC Delegation to the Republic of Korea online). The EU also is a leading investor and a major source of tourists for the two countries and the whole region. In turn, Japan is EU's fifth and Korea is the EU's eighth largest trading partners. 
Economic interaction between Europe and Asia is no longer the only priority in the dialogue between the two regions. As outlined by Gilson (2002: 110), the multilevelled formal political contacts between Europe and Asia as the whole (and East Asia in particular) are diversifying and including multilateral interactions within international political and economic organizations (e.g. UN or WTO) and various international forums (dedicated to such issues as nuclear proliferation, security, human rights, environment and more), interregional (e.g. ASEM, the EU's dialogue with ASEAN), bilateral (the EU's dealings with individual Asian countries) and country-to-country level (EU member states in their relations with individual states in Asia). Additionally, a range of EU strategic policies has been subsequently adopted towards Asia in general (1994, 2001), China (1995, 1998, 2001, 2003, 2006), South East Asia (1996, 2003), and toward two relevant countries - Korea (1993, 1996, 2001) and Japan (1991, 1995, 2001).

The current activation of the contacts between Europe and the two East Asian states are even more prominent on the historical background of limited links. Neither was previously colonized by European powers and both featured extensive periods of insularity in their histories resulting in distinct, rather isolationist, nationalistic attitudes. Yet, despite these attitudes, Japan was argued by Jackson (2004) to maintain minimal but 'continuous contact with the West since the mid-sixteenth century'. Japan's contacts with European traders were initiated in the sixteenth century through interactions with the Portuguese and Dutch (and to a lesser extent with the Spanish and English) (see e.g. Boxer 1979). A small late eighteenth century settlement of Dutch traders next to Nagasaki was credited by Goodman (1986:17) a reputation of 'Japan's window on the Western world' . The Dutch-Japanese contacts helped Japan to learn about European cultures, religion, art, science and technology. Japan's exposure to Europe in the early twentieth century featured several powerful links: Japan was the first Asian power to strike an alliance with a major European power, Great Britain, in 1902 (Roberts 1999: 209), and the first to defeat a major European power, Russia, in 1905. Moreover, in the beginning of the twentieth century, Japan trained its military in Europe (army in Germany and navy in Britain) (Ibid.) In contrast, for European powers, Korea (an independent kingdom between the seventh and twentieth centuries) remained in the shadow of the more politically assertive and more trade attractive Japan and China. Before the twentieth century, the most visible contact with Europe was Korea's exposure to European missionaries in early nineteenth century (Hara 
1998). The end of the Russo-Japanese War in 1905 resulted for Korea in the status of a 'protectorate' of imperial Japan. In the next five years Korea was annexed and became Japan's colony. Korea's independence was restored only in 1945, after Japan surrendered to the US after the Second World War.

It is obvious that Japan and Korea share a number of differences on institutional, cultural, political and media levels. The cleavages of comparisons are incredibly rich, deep and far beyond the scope of this paper. A cursory list of the most important distinctions would include linguistic and demographic peculiarities: in 2008, the population of Korea was 49 million people and 127.5 million in Japan (CIA online); economic divergences: Japan is the largest and the most diverse economy in Asia and the world's second-biggest economy (The Economist 2008: 13); Korea is the third largest economy in Asia and the twelfth largest in the world (IMF 2007); and differences in political profiles: Japan is a constitutional monarchy with a parliamentary government; Korea is a presidential republic. Unlike Japan, Korea has a very short history of democracy, and even though democracy now seems to be a reality in Korean society, Shin and Lee (2006) argued that the democratic transition is still under way, and Korea's political life is often turbulent.

As early as 1994, Sasae (1994: 50) noted that 'Japan's increasing emphasis on trilateral cooperation between itself, North America and Europe . . calls for the strengthening of the Japan-Europe side of the triangle.' Japan features an ongoing foreign policy preference for its relations with the US and for its bilateral relations with individual European states. To make dialogue even more challenging, according to Bridges (1999: 45), 'only a minority of EU states have a rounded relationship with Japan' in this bilateral pattern, with the UK being the lead. In its international relations, Korea is constantly aware of the dominating presence of a traditionally strong Japan, an increasingly dominating China and the omnipresent US. Similar to Japan, the US also remains the current main non-Asian focus for Korea's international relations. In Korea's relations with Europe, however, two events, one in the political domain, the other in the economic, seem to stress a multilateral focus in the EU-Korea dialogue. The former is the EU's informal role in negotiations on the Korean peninsula - arguably a key issue in Korea's security considerations. The latter is the Korea-EU Free Trade Agreement (FTA) with the $\mathrm{EU}$, which is nearing its conclusion and is becoming an increasingly visible issue in Korea's public debate focusing on trade and business exchanges with the Union. 
Yet, despite their divergences, both states are geo-political neighbours with an affluent presence in Asia and in the world. They are the only two Asian countries in the ranks of the Organisation for Economic Cooperation and Development (OECD), an organization that unites 30 member countries on the basis of 'sharing a commitment to democratic government and the market economy' (OECD online). Within the framework of the OECD, Japan and Korea are cooperating extensively with the Commission of European Communities and 19 EU member states. Throughout the twentieth century these two nations both experienced significant 'Western' cultural influence in their processes of economic 'modernization', and these influences came with a distinct American 'flavour', attributed to the recent war histories. While Japan was defeated by the US in the Second World War, Korea was supported by the US and the UN in its Civil War against the Communist Forces of the North. The US still keeps a hefty military presence in Korea. Both countries keep enjoying a very close relationship with the US, which includes numerous economic, political and even cultural alliances. The US has achieved a high level of influence on Japanese and Korean elite policy makers as well as the public imagination. For example, the popular culture is heavily dominated by American production and influences, young people from these two countries aspire to get their education in the US and the US remains a highly desired location to emigrate. ${ }^{3}$ Importantly though, while the US remains a top priority in external relations for both Japan and Korea, the mercurial rise of China as a trading partner may yet become a catalyst for change in how they set themselves with other global players in years to come.

\section{Theoretical Framework and Methodology}

In general, image studies like this directly serve the market research standing behind place branding campaigns. The importance of such an image study in the context of place branding is explored in the relevant literature (see Jaffe and Nebenzahl 2001; Morgan 2004; Ooi 2004). When it comes to the studies of EU political imagery, empirical studies are new and few. Several studies center specifically on the EU's images in Asia's powerful three-China, Japan and India (Shambaugh et al. 2007; Tsuruoka 2006; Lisbonne-de Vergeron 2006, 2007). Yet, these investigations do not employ comparative approaches across the locations. A number of studies looked at the EU's perceptions among international stakeholders (Murray 1999, 2002a, 2002b; EuropeAid 2003, 2007; Elgström 2006). 
A small group of projects touched on EU external perceptions in largescale international surveys (Bertelsmann Stiftung 2006; GARNET 2007, 2009; US German Marshall Fund 2006). One of the most comprehensive, up-to-date investigations in the field is a pioneering study of EU perceptions in the Asia-Pacific (Holland et al. 2007; Chaban and Holland 2008). This empirical, highly systematic analysis of the EU's images in the public discourses of mass media, the general public and national policy- and decision-makers started in 2002 and involved 19 locations in the region, ${ }^{4}$ comparing perceptions across space and time in one global region. This paper is a part of this large-scale research, zooming in on the state of EU perceptions in the two influential Asian countries of Japan and Korea. In particular, this paper focused on comparing the EU's visibility and framing in the reputable national newspapers with the perceptions of the EU's importance detected in the analysis of the public opinion in these two East Asian countries.

A complicated and constantly evolving cognitive input on international realities results in rather ambiguous processing of that information among the members of the general public. This inherent cognitive complexity is further aggravated by what Wodak (1987) believed to be a deficient ability of a member of the general public to challenge the discourses or information they are exposed to - when it comes to external relations, members of the general public often do not have the necessary knowledge and beliefs. Indeed, the general public typically profiles little first-hand personal exposure to foreign lands and people and exhibits a limited usage of alternative sources of information (e.g. everyday interpersonal communication on matters of foreign policy and external relations). Respectively, van Dijk (1998) argued that in the formation of public opinion about foreign issues, ordinary people remain largely passive targets of political text or talk.

One of such influential political discourses is news media. It would be an exaggeration to say that news media is the only source and shaper of current political information on nations' foreign counterparts. Yet, the relevant research argued that news media's potential is strong in the construction of images of the nation's external partners and in informing and educating the citizenry on foreign policy issues. News power in shaping mass perceptions and particular evaluative implications of how audience members judge other nations is well documented in the literature (Ball-Rokeach and DeFleur 1976; Palmgreen and Clark 1977; Adams 1987; Edelstein 1993; Albritton and Manheim 1983; Manheim and Albritton 1984; Perry 1985, 1987, 1990; Livingstone 1997; van Gin- 
neken 1998; Soroka 2002; Brewer et al. 2003; Cohen 1963,1965; Larson 1984; Davison et al. 1980). Galtung and Ruge (1965: 64) famously noted that 'the regularity, ubiquity and perseverance of news media will in any case make them first-rate competitors for the number-one position as international image-former'.

Grounding this inquiry into the EU's external images in the 'common knowledge' paradigm of political communication studies (Neuman et al. 1992), ${ }^{5}$ this paper focuses on how political information is organized and structured in the public discourses of different media in Japan and Korea, and how that information compares with public perceptions in these two countries. According to Neuman et al. (Ibid.), the use of common knowledge theoretical paradigm advocates investigating a 'three-way interaction of individual, medium, and issue,' emphasizing a 'more balanced inquiry into the interaction of media, media message, and public understanding,' (Ibid.: 16) and calling for 'the systematic integration of multiple methodologies,' (Ibid.: 19) (in our case, content analysis of media texts and public surveys).

This research assumes that subtle but nevertheless powerful effects of mass media may lie in their selection and presentation of certain issues (and non-presentation of the other issues) (Roessler 1999). The pure visibility approaches (studied in classical agenda-setting) (McCombs and Shaw 1972) argue that increased visibility of a subject in the media raises the salience of this subject amongst the audience. The relationship between media and the public agenda is the main focus of most agenda-setting studies (Protess and McCombs 1991). In this approach, a traditional view on media influences - i.e. media tells the audience 'what to think' - transforms into a question about media effects - i.e. media prompts the audience 'what to think about' (Cohen 1963; McCombs and Shaw 1972). Framing approaches (studied in cognitive linguistics and critical discourse analysis) ask how something is presented. Respectively, the question of media influences includes a new element-media tells the audience 'how to think about' an issue. Combination of the two abilities of media - to raise an issue's visibility and frame this issue in a particular way - allows this paper to assess which EU-related events, actors and issues become news for the Japanese and Korean public, how much volume and intensity this information is granted by the local newsmakers and how the EU is reported.

Choices made by the newsmakers, either intentional or accidental, are inevitable. Indeed, media professionals cannot possibly report an infinite number of events happening domestically and internationally; 
and in their mission to 'inform, educate and entertain' (Reith as cited in Thussu 2007: 20), they select events and construct narratives so that 'apparently scattered and diverse events [can be] understood within regular patterns' (Norris et al. 2003: 11). These constructed narratives, or media framings, emphasize only certain aspects of a represented reality providing information and guidance for the public, in the words of Entman (1993: 52), through the 'selection of some aspects of perceived reality to make them more salient in a communication text, in such a way as to promote a particular problem definition, caused interpretation, moral evaluation and/or treatment recommendations.'

With media framings of international counterparts arguably possessing a stronger effect on public opinion on foreign issues, the mass media is assigned here a special role in the formation of public perceptions by providing the public 'with a new vocabulary of motives for the purpose of accounting for or rationalising the policies and actions of the government' (Movahedi 1985: 20). This 'activation of concepts in human memory due to the media exposure resulting in the heightened accessibility to the concept' (Brewer et al. 2003: 494) underlines the notion of priming of certain concepts by the public and overlooking of other concepts. It is argued that primed patterns of media visibility and framing are more likely to correlate with particular visions of the foreign counterparts including their perceived importance to the nation in question (however, this paper would like to reiterate that the perceived importance is not the direct function of the public's exposure to media, but to a complex combination of many other factors of which media is one).

Importance is believed to be a key in determining which policy areas are likely to be focused on by a government in order to maintain a favourable profile with their public. Even foreign policy conception and execution (argued by Moisy 1997 to be a prerogative of a limited and selected group of highly trained elites in any society) experience the weight of importance assigned to an issue by individual members of the public (importantly, voters and taxpayers). Fournier et al. (2003: 53) observed the more important an issue is perceived to be, the 'more likely to rely on their attitudes toward that issue (individuals will be) when evaluating (government) candidates'. Of note, Japan and Korea, the two democratic OECD societies in Asia, share a common belief in the free media (interpreted by A. Smith (1980: 14) as 'separation of power between the press and government') as well as a recognized and supported opportunity for the general public to express its opinion in all spheres of public life, including foreign policy. 
Respectively, this paper aims to investigate the imagery projected of and by the EU in Japan and Korea in two types of public discourse - national reputable newspapers and the general public opinion. Reputable national newspapers are seen as an 'important source of information and a potentially powerful lobbying force on ... [democratic] regimes' (Rubin 1979: 7). Despite the current decline in circulation (Anderson and Weymouth 1999: 15), they still serve as news leaders and agendasetters for other mass media (Larson 1979), while being preferred by more educated, cosmopolitan and older audiences (Stempel and Hargrove 1996), among those, national elites (Schulz 2001). The focus on general public opinion (vs. elite opinion) was grounded in the fact that public opinion is often overlooked in studies related to foreign policy execution in general, and the EU in particular. The leading rationale behind this research choice is that a comprehensive account of international general public opinion could be of great significance for the EU's maturing foreign policy and, specifically, its neglected locus of public diplomacy discussed above. In this context, raising the EU's profile and positive image becomes an urgent and vital necessity for the Union's problematic international identity.

The data for this research came from a transnational comparative project 'The EU through the Eyes of Asia' currently undertaken in twelve Asian locations, including Japan and Korea (2006-08). ${ }^{6}$ Study in both locations employed identical methodologies in media content and general public opinion analyses, thus ensuring comparability of the findings in each phase. The project gathered unique data never collected before in such a systematicity and scope. In public opinion analysis, a 25-question pre-tested questionnaire (with six open-ended questions) was applied to a sample of 400 people (18 years and older) in each case. The margin of error was \pm 4.9 percent. These surveys (in Japanese and Korean respectively) were administered online taking into account a high level of computer literacy in both countries. ${ }^{7}$ Media-wise, identical sets of content analysis indicators were applied to analyse EU daily coverage in the three reputable national newspapers in 2006 - a special year in the EU-Asia dialogue featuring a biannual ASEM meeting in Helsinki. More specifically, the study monitored daily coverage of the EU in prestigious national papers with the highest circulation; then, in the most popular business daily, and finally, in an English-language local newspaper. While the papers of the first type (Chosun Daily in Korea and Yomiuri in Japan) were seen as reaching a broad demographic in each country, the 'business' dailies (Maeil Business Newspaper in Korea 
and The Nikkei in Japan) were seen to be read by members of the business community - those who potentially invest in and trade with the EU. An English-language newspaper in each case (Korea Herald in Korea and The Japan Times in Japan) was argued to provide information on the home country to the foreigners outside those two countries, expatriates inside those two countries, locals living outside their home countries, younger educated locals inside the countries willing to improve their English, as well as international media searching for information on the two localities. Chosen newspapers (especially 'popular' and 'business' ones) are among the highest in circulation in the world (see World Association of Newspapers online).

Agreeing with the EU international identity studies postulate formulated by Manners and Whitman (1998: 246) that 'the global role of the European Union as being greater than the sum of its parts', this investigation sampled news texts that had to reference the communal concept of the 'European Union/EU' at least once, even briefly. In addition, a search was also conducted for the communal EU institutions of the 'European Commission/EC', 'European Parliament/EP', 'European Central Bank/ECB', 'European Court of Justice/ECJ' and the 'Asia-Europe Meeting/ASEM'. The sample size was an impressive total of 1,787 news texts -927 news items from Korea (monitoring period 1 January-31 December 2006) and 860 from Japan (monitoring period 1 January-31 June 2006). The Union's existing communal economic weight and an emerging political profile matters both internally and externally, yet this study of EU external perceptions is clear that understanding the EU, as a unique political concept, presents certain difficulties for outsiders. First, as discussed above, its definitions of a political entity oscillate between a supranational state and a loose inter-governmental organization. This study clearly recognizes that the EU is not a state; nevertheless, it registers that the media and political discourses inside and outside the Union extensively compare the EU to a state in their categorizations. Indeed, Manners and Whitman (1998: 237) claimed that the EU is generally addressed and understood by its external partners in a capacity similar to that of a state. Second, the study acknowledges that the EU is made up of diverse countries, with their own self-interests, which sometimes diverge from the EU's communal ones. Moreover, as discussed above, historically some EU countries are better known than others in Japan and Korea.

Being conscious of these dynamics, this study chooses to limit its research focus to studying the images and perceptions of the concept 'EU' (and its communal institutions of EC, EP, ECB and ECJ). A similar 
research focus could be located in the relevant voluminous research of the EU images and representations within the EU (see research of the Amsterdam School of Communication Research; ${ }^{8}$ Anderson and Weymouth 1999; Gavin 2000; Kevin 2003; Trenz 2004). In this case-study, the EU is seen as a categorization representing to the world an emerging economic and political project - a unique, novel, constantly evolving, integrationist (on a volunteer basis) and peaceful political communal entity on the European continent, studies of which are still in their formative years. This research choice obviously has its advantages and limitations. Prioritizing the analysis of external images and perceptions of the EU as a valid and novel subject of research, this study did not search for news referencing all 27 individual members states on a separate basis. However, the content analysis took into account the references to those states when they appeared in the news items that mentioned the EU (or EC, EP, ECB or ECJ). The coding protocol differentiated between news items that reported the EU as a major actor (with an EU state acting as a secondary or minor position) or a member state as a major actor (with the EU being presented from a secondary or a minor perspective).

Articles relevant for EU reporting were selected from all parts of the newspapers. All texts in this paper came from electronic archives of the newspapers, warranting a high reliability and accuracy of the data. Considering the main questions of media analysis - what are the patterns of the EU visibility and framing in the newspapers - the content analysis used a mixed method, combining qualitative and quantitative approaches, looking both across large aggregates of texts to identify patterns in the EU's media portrayals and then focusing on nuances of the EU's framings within sampled texts. Identified media frames were subsequently compared with the dominant perceptions and images of the EU among the Korean and Japanese general publics.

\section{Results}

\section{Media Visibility and Framing}

In media analysis, visibility - or which EU-related events became news and how much volume and intensity this information was granted - was assessed using such indicators as volume and frequency of the EU news and its main actors, distribution of the foci of domesticity (internal vs. external grounding of the EU actions in news to the country of reportage) and degrees of centrality (intensity of EU's news representations - minor, 
secondary or main). With regards to the two last indicators, a higher proportion of representations with local grounding and with major intensity was believed to convey a higher factor of importance of a foreign counterpart to the local readers. Regarding the first indicator, higher volume and frequency of a foreign actor indicated greater salience assigned to it by local readers.

In both countries, business dailies were the leaders in the EU coverage, possibly reflecting reality of the EU, which remains a major economic

FIGURE 1: Monthly average of news texts referencing the EU in Japan and Korea, 2006

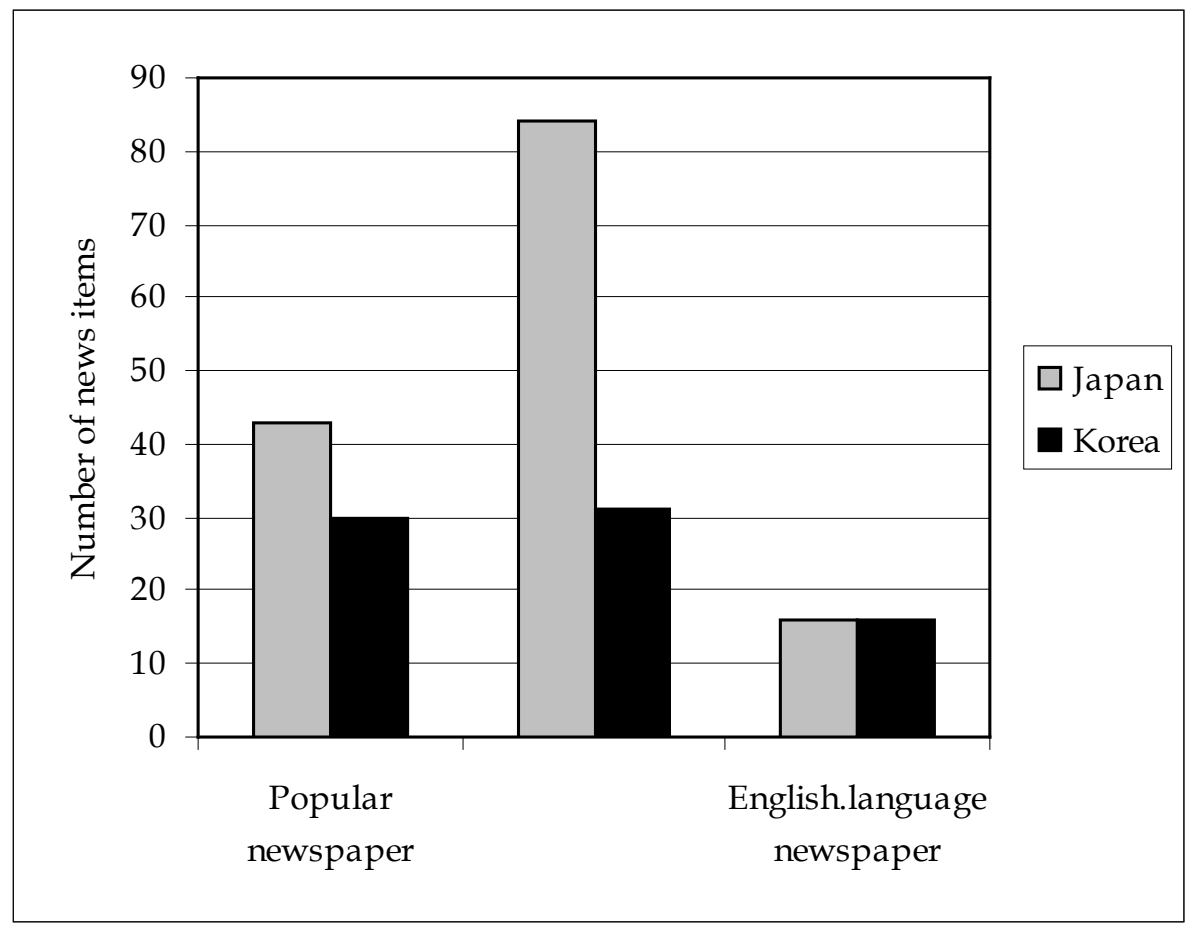

partner for the two countries (Figure 1). Predictably, the most interest in EU matters is expected to come from among the business and financial 'elites' - those who invest in and trade with the EU. However, in Korea, the popular newspaper closely followed the business publication in its coverage of the EU, while in Japan the output of the EU news in the popular newspaper was almost half that of its business counterpart. Attention to the EU from the Korean popular daily could be attributed to the FTA with the EU prominently discussed in 2006 in Korea and an intense interest in the issue in all parts of Korean society. In both countries, the English-language newspapers were the least interested in 
reporting the EU and, surprisingly, featured an identical monthly average of 16 news items per month. The finding is somehow paradoxical taking into account the profile of the readership, namely 'Western' expatriates, internationally-minded locals and foreigners residing outside the borders. It seems that reports of the locality's interactions with the EU (an important economic and political counterpart) are of no priority to the newsmakers in these outlets.

Sourcing of EU news deserves a special mentioning here. High in circulation and wealthy, Japanese and Korean 'popular' and 'business' newspapers have numerous foreign news bureaus posted around the world, including Europe. ${ }^{9}$ Respectively, most news in Japanese and Korean popular and business press is written by local correspondents, either directly from Europe or domestically. When EU news came from international wires (observed more frequently in the English-language newspapers) ${ }^{10}$ three sources were dominant - Reuters, Associated Press $(A P)$ and Agence France Press (AFP).

Realizing that it could be unfair to compare countries and regions (most new stories relate to specific countries rather than regions), this study nevertheless was interested in looking at how the coverage of the EU (and its communal institutions) compared to the coverage of the US. With the EU often labelled in international rhetoric to be a 'superpowerin-waiting', it is increasingly described as a highly plausible international 'counterbalance' and 'check-and-balance' to the US (which, in contrast, is frequently described as the 'only remaining true super-power'). It was found that the EU's coverage in the newspapers was far lower than the volume of news reporting the US as a major international actor. In a parallel study, visibility of the EU in the three major Japanese newspapers, The Daily Yomiuri, The Asahi Shimbun and The Nikkei, was compared to the visibility of the US. Using Lexis/Nexis media database to locate news texts referencing 'European Union/EU' and 'US' over two years (from 1 May 2004 to 31 May 2006), the study revealed that the US was mentioned almost ten times more than the EU (Chaban and Kauffmann 2007). However, this finding should be put in a perspective-the cited study did not evaluate how often Germany, France, the UK and other EU member states were mentioned during the same period.

The visibility of EU actors and institutions was also assessed. The most visible EU institution in Japan's reportage of the EU was the ECB (mentioned on average 21 times per month in the three newspapers). This could be attributed to a significantly higher monthly share of EU news in the business newspaper. The European Commission (EC) was 
second, averaging 19.5 references per month. In contrast, in Korea, the EC was more visible than the ECB. Yet, both institutions were much less visible than in Korea - six references per month on average for the EC and 2.25 for the ECB in the Korean press. Uniquely for Korea, the EU Chamber of Commerce got some media visibility with two references per month on average. In both countries, the European Parliament and respective EC Delegations were mentioned very rarely.

In economy-related news the EU officials in charge of trade and the ECB were the most visible EU figures in both countries - EC Trade Commissioner Peter Mandelson and ECB President Claude Trichet. Other commissioners involved in EU economic decision-making were reported seldom (among those, EC commissioners for Competition, for Economic and Monetary Affairs and for Energy). In the political coverage, EU High Representative for the Common Foreign and Security Policy Javier Solana and EC President José Manuel Barroso were the most reported across both cases, with Solana being featured as the most visible face of EU political activities. In contrast, other prominent officials in the EU external relations - EU commissioners responsible for External Relations and for Development and Humanitarian Aid - were reported only occasionally. Japan's environmental reportage infrequently profiled EU commissioners for Environment and for Industry. Other commissioners remained out of the press spotlight. In particular, social coverage in Korea and Japan mostly referenced EU institutions, not EU leading representatives. It is suggested that for Asian newsmakers, discussing individuals (who are presumably unknown and unrecognized by the local public) may compromise the relevance of the articles to the average reader.

To the question of the EU vs. individual EU member states reporting, in general, the most visible EU member states in the reporting of the EU in Japan and Korea were the EU's 'Big Three' - the UK, France and Germany. Finland, a host of the sixth ASEM meeting in September 2006, and Denmark, a home country to a controversial media outlet that published a caricature of Prophet Mohammed, also got their share of media attention in that year's coverage. The UK and Germany were presented as the most active actors in environmental news. Poland and the Czech Republic led the coverage of EU new members. Other member states received minimal media consideration in the context of the EU.

The study also evaluated the degree of centrality of the EU news representation. Following the suggestion by Kevin (2003: 54), the three categories depicted the EU as a main, secondary or minor theme of reportage. The Japanese and Korean press coverage prominently profiled the 
EU from a minor perspective (58 percent and 60 percent of the coverage respectively) followed by a secondary angle (28.5 percent in Japan and 26 percent in Korea). Main degree of intensity in the EU reporting was traced only in 11.5 percent of publications in Japan and 16 percent in Korea. A leading minor/secondary degree of centrality suggests the relative unimportance of the EU to the country or media in question, emphasizing again the EU's low visibility I the Korean and Japanese press.

Adapting classifications of foreign news suggested by Schulz (2001) and Peter et al. (2003), this paper recognizes three foci of domesticity in reporting the EU to readers. The first one is internal contextualization of the EU-events and actions happening inside the Union and having direct consequences to the EU ('EU in Europe'). The second type of media framing contextualizes the actions of the EU as an international agent whose activity primarily influences a third party - neither the EU, nor Korea or Japan in our case ('EU abroad'). Finally, the third type of framing depicts the EU's actions as having direct consequences to the local stakeholders and grounds the EU as an important domestic interlocutor ('EU at home'). The three newspapers in each country prominently reported the EU in an 'EU-abroad' context (47 percent of the EU coverage in the Japanese press and 41 percent in the Korean). The 'EU-abroad' context-the EU acting 'somewhere out there in the world' and on a minor scale-indicated that the EU's actions were not portrayed as having immediate local relevance for both Japan and Korea, and created an image of the EU as a marginal international actor. Yet, notably, a finer difference was observed in the economy-related EU coverage. In the Korean press, the EU's economic actions were reported from a main perspective and located in the 'EU-in-Europe' context (such profiling is probably due to the FTA theme dominating press coverage in 2006). In the Japanese case, economic framing of the EU positioned the Union as a secondary theme (presenting the EU's economic activities within the context of the EU member states, more specifically the UK, Germany and France).

Framing of the EU - or how the EU was represented to the audience was assessed in terms of four thematic priorities assigned to the EU's media portrayals, namely the EU as Political Power, the EU as an Economic Power, the EU as a Social Affairs Actor and the EU as an Environmental Actor. Media coverage of the EU in Japan and Korea was also assessed in terms of the tone of reportage-coders of the media texts, native speakers of the Japanese and Korean currently living and working in the two locations, categorized the tone of the EU representation as positive, neutral 
or negative. Coders were educated and informed researchers sensitive to the peculiarities of the local language and knowledgeable of the local discourses to make informed judgments on the tone of reportage.

Firstly, this analysis looked into proportional distribution of the four leading thematic media frames (Figure 2).

It is important to note that 2006 was a so-called 'routine' year in the EU's internal life, but a rather special year for its interactions with the Asia-Pacific: in September 2006, the sixth ASEM summit took place in FIGURE 2: Framing of the EU in the Japanese and Korean Press, 2006

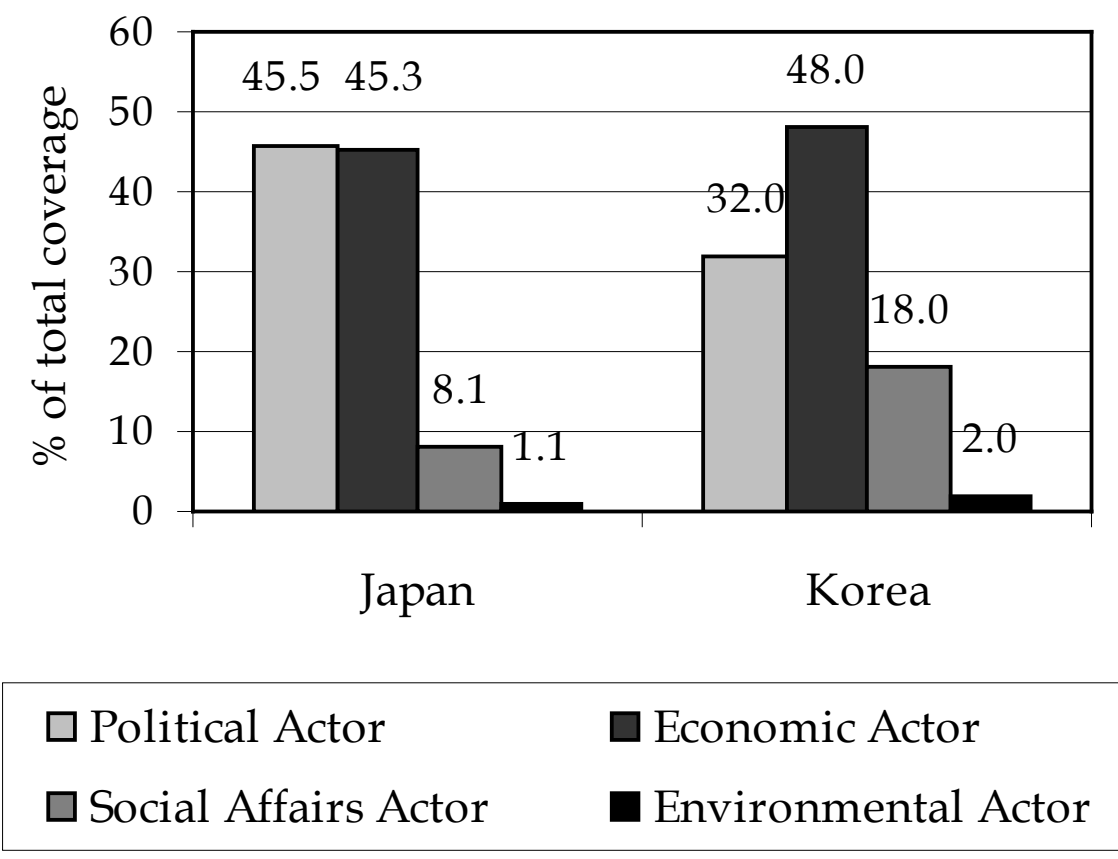

Helsinki. Coverage of exceptional political events (such as summits) in 'routine' years usually only peaks during these events and is much less consistent throughout the year. Taking into account the year of reportage, it is interesting to observe that in Japan the EU's media visibility in political and economic terms was almost equal, with a slight lead of the political representations (possibly indicating Japan's growing awareness of the EU as a political, and not just an economic, actor). By contrast, in Korea, portrayals of the EU as an economic actor led by the FTA themes dominated public discourses in 2006. However, a previous study of the Korean coverage of the EU in five newspapers in 2004 (a special year in the EU's existence, which featured several major political events) still 
showed that economic themes dominated the coverage (Chaban and Holland 2005). Korean press also paid more attention to the EU as social affairs actor-proportionally to the volume of coverage, social topics appeared twice as often as in Japan. Representations of the EU as an environmental actor were minimal in both countries' sampled press.

Coverage of the EU's economic activities revealed a set of five major themes - trade, agriculture, business/finance, state of economy and industry (Table 1). With the EU-27 being among the top trading partners to the two countries in the study, trade-related topics consistently ranked very highly in all cases. However, in Japan, trade coverage was eclipsed by reporting of business/finance issues. The state of the EU's economy was mentioned frequently in Korea, reflecting the Korea-EU FTA negotiations - a state of the Union's economy was seen as a key indicator for the agreement to go ahead or stall. Industry coverage was consistent, yet, somehow surprisingly, relatively low in visibility among the two samples. With both Korea and Japan being highly industrialized countries whose economic interactions with the EU involve a significant proportion of industrial links, the topic was expected to get more attention from newsmakers. Agriculture-related articles were almost invisible (even though the agricultural sector in Japan is small, it is heavily subsidized and the issue of the EU's Common Agricultural Policy (CAP) remains of concern to Japan).

TABLE 1: Distribution of the topics within the economic thematic frame (in percent)

\begin{tabular}{|l|c|l|c|c|c|c|}
\hline & Trade & $\begin{array}{l}\text { Business/ } \\
\text { Finance }\end{array}$ & Industry & $\begin{array}{l}\text { State of } \\
\text { Economy }\end{array}$ & Agriculture & Other \\
\hline Japan & 29 & 52 & 13 & 4 & 1 & 1 \\
\hline Korea & 38 & 15 & 17 & 22 & 1 & 7 \\
\hline
\end{tabular}

The distribution of political sub-frames - EU Internal Policy-Making and EU External Actions - revealed a common pattern for the press in both countries. Most articles in Japan and Korea were found to prioritize reporting of the EU's external actions: 72 percent of the political frame news items in Japan and 81 percent in Korea. This suggests that the Japanese and Korean newspapers were more interested in the role of the EU as a global player than in the EU's internal political developments as a unique supranational organization. Even though such representations indicate that the EU is recognized by the media of the two Asian affluent countries as a visible actor in world affairs, it also shows 
that the Korean and Japanese newsmakers do not feel that its internal actions are very important to their readers, suggesting the presence of a certain psychological distance from the EU. It must not be forgotten that 2006 was a year involving the ASEM meeting, thus EU coverage was expected to have more visible 'local' connections to Asia in general, and to Korea and Japan in particular.

Reporting of the EU's external activities followed four major themes EU dealings with the Middle East, the US, China and North Korea, with coverage of the EU actions in the Middle East dominating in both countries (Table 2). Reportage of the Middle East-EU relations reflected the efforts of the EU to negotiate peace agreements in this region, as well as nuclear issues, with the EU being presented as a major negotiator - the role, which seems to be of relevance for the East Asian countries involved in the 'Six-Party Talks' negotiating situation with regards to North Korea. With Japan's and Korea's traditional and long-lasting links with the US, the visibility of the next topic - the EU-US relations - was hardly a surprise. Between the two locations, this topic got a higher share of attention in Japan. The EU was shown as a visible player in world politics, whose relations with the US constitute leading interest to Asia in general and to its economic and political leaders-Japan and Korea. Coverage of EU-China relations also enjoyed some prominence, but only in the Japanese reportage. This suggests that relations between the big players in the world, namely, the US, the EU and China are of great importance to Japan, which sees itself as a major international actor. In contrast, the Korean press seemed to ignore the topic of EU-China interactions, instead stressing reportage of EU dealings with North Korea. It was the second most important political topic in Korea.

TABLE 2: Leading topics in the coverage of the EU political news (external politics sub-frame)

\begin{tabular}{|l|l|l|l|}
\hline Countries & No. 1 & No. 2 & No. 3 \\
\hline Japan & Iran & EU-US & EU-China \\
\hline Korea & Middle East & North Korea & EU-US \\
\hline
\end{tabular}

Portrayals of the EU's social actions were among the two least visible frames and did not create an adhesive and powerful image of the EU as a social affairs actor. However, certain patterns managed to emerge. Such themes as education and research, migration, social legislation, multicultural matters and entertainment got their share of media attention (Table 3). 
TABLE 3: Distribution of the topics within the social affairs thematic frame (in percent)

\begin{tabular}{|l|c|c|c|c|c|}
\hline & $\begin{array}{l}\text { Education } \\
\text { and research }\end{array}$ & $\begin{array}{l}\text { Migration } \\
\text { matters }\end{array}$ & $\begin{array}{l}\text { Social legis- } \\
\text { lation }\end{array}$ & $\begin{array}{l}\text { Multicultural } \\
\text { matters }\end{array}$ & $\begin{array}{l}\text { Entertain- } \\
\text { ment }\end{array}$ \\
\hline Japan & 30.8 & 8.8 & 15.4 & 1.4 & 0.0 \\
\hline Korea & 15.4 & 4.0 & 10.3 & 2.8 & 6.8 \\
\hline
\end{tabular}

Research and education articles led the EU's social affairs coverage in both countries, with Japan's press focusing more intensively on the EU as an entity promoting research and education. In Japan's case, the reputation of the place as the home of the latest technological and industrial advances makes the Japanese readers' interest in the EU's corresponding activities predictable. The Japanese press reported numerous joint research ventures with the EU as well as several competing research projects. In Korea, media reported on the EU's universities and various education opportunities for Koreans in Europe. This particular media framing possibly reflected the importance assigned to education in Korean society and the fact that many Korean families send their children abroad to achieve internationally recognized degrees. The Japanese media discourses also featured a larger (when compared with Korea) share of news reporting the EU's migration issues. Certain parallels to Japanese illegal migration problems, namely an increased illegal labour mobility from poorer Asian countries to more prosperous centres, may explain this media attention. Social legislation attracted some media interest in both countries and included the coverage of the EU regulations concerning the amount of working hours in the EU countries, of the EU's policies on equal job opportunities and the EU's regulations establishing poverty minimum. Korean newspapers devoted some attention to the EU in the context of entertainment. In contrast, the Japanese news sample did not feature EU news on this topic (entertainment was seen to be produced by individual European states rather than the Union).

The EU's multicultural and multireligious situation in general, and the 2006 scandal around the caricatures of the Prophet Mohammed in particular, got a relatively low share of attention in both Korea and Japan, possibly due to marginal Muslim demographics in both countries. It is also possible that most of this news coverage occurred in items referencing only Denmark (and missing the EU references). However, it is important to notice here that the study of Japan's and Korea's imagery of the EU in 2006 was conducted in parallel to the same study in the two South East Asian locations of Singapore and Thailand. A similar 
media sampling procedure (i.e. looking for news texts featuring references to the EU) revealed a different picture: the topic of the Prophet's portrayals was among the leading ones in the EU's social affairs media framing. The two South East Asian countries feature sizable Muslim minorities, and the issue (considered to be an EU issue and a Danish one at the same time) was seen to have a prominent 'local hook'-Europe was portrayed as not a very welcoming place for Muslims. Importantly, in all locations in the study (North and South East Asian), the EU-referencing reportage of the scandal around the caricatures was positioned not only in the context of an individual member state (Denmark), but in a broader European/EU frame. When the conflict was followed by Asian media, it was presented from a point of a controversial theory of the 'civilizational clash' argument developed by Huntington (online).

The actual number of the news items reporting the EU's environmental actions was very low in both Japan and Korea, thus this paper presents a very general summary of the most visible (yet still very limited in visibility) topics (Table 4). Framing of the EU as an environmental actor was categorized in dual terms - portrayals of the EU's actions in relation to industry functioning, as well as actions in relation to the development of the relevant policies. $\mathrm{A} \mathrm{CO}_{2}$ emissions focus in the EU reportage was traced in both locations. Predictably, these heavily industrialized economies face growing challenges when tackling carbon emissions. The Japanese media extensively reported talks in Nairobi and the future of the Kyoto Protocol. With the two countries being signatories of the Kyoto protocol on par with the EU and its member states, this interest is predictable.

TABLE 4: Most visible topics representing the EU in the field of environmental affairs

\begin{tabular}{|l|l|l|}
\hline & Japan & Korea \\
\hline \multirow{2}{*}{$\begin{array}{l}\text { Industry and environ- } \\
\text { mental actions }\end{array}$} & $\mathrm{CO}^{2}$ emissions \\
\cline { 2 - 3 } & aviation & \multicolumn{2}{|c|}{} \\
\cline { 2 - 3 } & & \multicolumn{2}{|l}{ new energy } \\
\hline \multirow{3}{*}{ Environmental policy } & climate change & \\
\cline { 2 - 3 } & waste treatment & air pollution \\
\cline { 2 - 3 } & &
\end{tabular}

In both countries a neutral tone dominated the EU's reporting: 88 percent of the Japanese sample and 67.8 percent of the Korean. Arguably, a dominant neutral tone of the EU coverage in both countries may 
indicate a certain degree of indifference to the EU topics on behalf of the newsmakers in the two countries. When evaluations were made, differences between the EU reportage in the two countries were more pronounced. While positive evaluations of the EU took a similar share in the overall coverage (12.5 percent of Korean news and ten percent of Japanese), in Japan, negative evaluations accounted for only two percent of the sample, while Korea's share was 19.7 percent. A strong neutral-topositive tone of both the Japanese and Korean reportage could also be explained by the need to follow the cultural notion of 'politeness' peculiar to Asian societies (such as those inherent in the concepts of honne and tatemae in Japanese society) (see also Hendry 1989). A higher share of the negative news in the Korean sample arguably could be attributed to a more acute debate on Korea's involvement with the EU in the context of the FTA in 2006 (there was no EU-Japan issue for debate that year in Japan similar in scale).

\section{Perceived Importance of the EU in Public Opinion}

In public opinion terms, the perception of the EU's present-day and future importance was assessed (Table 5).

TABLE 5: The importance of overseas partners for Korea and Japan

\begin{tabular}{|l|c|c|c|c|}
\hline \multirow{2}{*}{} & \multicolumn{2}{|l|}{ In the present } & \multicolumn{2}{l|}{ In the future } \\
\cline { 2 - 5 } & 1st Place & EU rank & 1st Place & EU rank \\
\hline Korea & US & 4 th & China & $4^{\text {th }}$ \\
\hline Japan & US & 6 th & US & $4^{\text {th }}$ \\
\hline
\end{tabular}

First, the respondents were asked to name which overseas countries or regions they thought were the most important partners for their respective countries at present. Respondents were given a list of 16 countries/regions, one of which was 'Europe/EU.' Responses were in the form of 'yes' or 'no.' Respondents could give multiple 'yes' answers. The list was presented to respondents in a rotating order. For all countries in this study, public perceptions de-emphasized the importance of the EU (Table 5). Respondents in both countries chose the US as the most important partner for their respective countries at present (74 percent and 82 percent respectively, a perception that echoes findings on media visibility of international actors). Despite the EU's impressive economic 
contacts with the two Asian countries, it is not winning the 'race' of present-day importance as perceived by the general public: in Japan, the EU was seen only as sixth in importance; for South Korea, a slightly higher ranking of fourth position was assigned.

The difference in intensity of importance assigned to the EU by the public in Korea stands out. While Japan featured 14.5 percent of its sample perceiving the EU as important, the Korean survey featured 41.5 percent of the respondents mentioning the EU as an important counterpart. This high intensity of responses could again be connected to the most recent and very important FTA talks with the EU, the EU's contribution to the security situation on the Korean peninsular (both broadly reported in the local media), as well as a Korean quest for a more balanced foreign policy (something discovered from the interviews with the Korean 'elites') (Chaban 2008).

Perceptions of the EU's importance in the future were also intriguing (Tables 5 and 6). The respondents were asked to rate the perceived future importance of a number of the countries and regions (including the EU). Respondents were asked to rate such regions/countries as EU/Europe (including the UK), North America, South America, Asia (excluding China and Japan), UK, China, Japan, Russia, ${ }^{11}$ and India ${ }^{12}$ in terms of their future importance to their respective countries (on a scale of one to five, one being 'not at all important', five being 'very important'). Both lists were presented to respondents in a rotating order. Major results are summarized in Table 6.

TABLE 6: Ranking of the future importance of the foreign counterparts

\begin{tabular}{|l|c|c|l|l|}
\hline & $\mathbf{1}^{\text {st }}$ place & $\mathbf{2}^{\text {nd }}$ place & $3^{\text {rd }}$ place & $\mathbf{4}^{\text {th }}$ place \\
\hline Japan & US & China & $\begin{array}{c}\text { Asia (excluding } \\
\text { China) }\end{array}$ & Europe/EU \\
\hline Korea & China & US & Japan & Europe/EU \\
\hline
\end{tabular}

A slight rise in the Union's positioning in perceived importance was observed in Japan - from sixth position at present to fourth in the future, and it remained on the same, fourth, level in Korea. Significantly, a much higher importance was assigned by the public in the two countries to the 'rising star' of China in the future. In Korea, China was assigned first place, and in Japan it became second (with the US still being seen as partner 'No.1').

In order to further compare how the most visible issues in media coverage correlate to the public opinion of the EU in both cases, the respondents 
were asked to rate 20 country-specific issues in terms of their perceived impact on each respective country (on a scale of one to ten, one being 'no impact at all', ten being 'huge impact'). These 20 issues corresponded to the most frequently mentioned topics, identified in content analysis of the EU press coverage. Results of the first question are in Table 7.

TABLE 7: Top five EU-related issues in terms of their perceived impact on the respective countries

\begin{tabular}{|l|l|l|l|l|l|}
\hline & $\mathbf{1}^{\text {st }}$ place & $2^{\text {nd }}$ place & $3^{\text {rd }}$ place & $\mathbf{4}^{\text {th }}$ place & $5^{\text {th }}$ place \\
\hline Korea & $\begin{array}{l}\text { EU dealings } \\
\text { with the US }\end{array}$ & $\begin{array}{l}\text { EU as a } \\
\text { trading } \\
\text { partner }\end{array}$ & euro & $\begin{array}{l}\text { EU's role in } \\
\text { the WTO } \\
\text { Doha Round } \\
\text { talks }\end{array}$ & $\begin{array}{l}\text { EU anti- } \\
\text { trust legis- } \\
\text { lation }\end{array}$ \\
\hline Japan & $\begin{array}{l}\text { EU's role } \\
\text { in the } \\
\text { WTO Doha } \\
\text { Round talks }\end{array}$ & $\begin{array}{l}\text { ECB } \\
\text { policies }\end{array}$ & $\begin{array}{l}\text { EU deal- } \\
\text { ings with } \\
\text { China }\end{array}$ & $\begin{array}{l}\text { EU dealings } \\
\text { with the US }\end{array}$ & Euro \\
\hline
\end{tabular}

The top five important issues for the Japanese respondents could be grouped into two clusters. They either concerned EU economic actions, such as the EU's role in the WTO Doha Round (in which the EU was siding with Japan against the US and Brazil), ECB policies (more specifically, interest rates and inflation rates) and the euro; or emphasized the EU's political dealings with such world powers as the US and China. These findings illustrate the public's visions of the EU, firstly as a counterpart important to Japan in the context of economic (business and financial) matters, and secondly as one of the 'big players' in world politics. It is possible that media's heightened visibility of the ECB (as discussed above, the most visible EU institution in the Japanese press, and much less visible in the Korean) correlates with a higher level of importance assigned by the Japanese public to this EU actor. Commenting on the second cluster of answers, Japan is argued to be a regional leader, thus its public ascribes heightened importance to the dynamics of the relations between Japan, the EU, the US and China - other global leaders.

In the Korean survey, importance assigned by the public to the economic issues was even higher than in the Japanese case. Such issues as the role of the EU as a trading partner to Korea, the EU's role in the WTO talks, and the impact of the euro were seen as greatly influencing Korea. These peculiarities of the public's ratings seem to reflect importance of international trade to Korea. In this context, a growing significance is 
being attributed to the trade relationship between the EU and Korea. However, the ratings assigned to the EU's economic actions were surpassed by the ratings given to the EU's dealings with the US - relations between the two geo-political 'giants' were of undeniable interest. It is somewhat surprising, however, that the EU-China relations were not perceived to have a great impact on South Korea in the present. This finding carries certain correlation to the results of the EU's framing in the press; as discussed above, the EU-China dialogue was practically ignored by the Korean newsmakers, with only five news items out of 927 touching on this topic. Nevertheless, as discussed above, China was rated as Korea's most important partner in the future in public opinion results. Arguably, personal knowledge, experience and interpersonal communication might be among alternatives to media factors that influenced this particular perception of China's future importance to Korea among the respondents.

Finally, in order to compare media framings of the EU with the public opinion of the EU, the respondents were asked to list three images (or spontaneous associations) that come to mind when they hear the words 'the European Union' (the top four associations for each country are summarized in Table 8 ).

TABLE 8: The most frequent spontaneous images of the EU

\begin{tabular}{|l|l|l|l|l|}
\hline & $\mathbf{1}^{\text {st }}$ & $\mathbf{2}^{\text {nd }}$ & $\mathbf{3}^{\text {rd }}$ & $\mathbf{4}^{\text {th }}$ \\
\hline Korea & $\begin{array}{l}\text { EU inte- } \\
\text { gration }\end{array}$ & Euro & $\begin{array}{l}\text { individual } \\
\text { countries }\end{array}$ & $\begin{array}{l}\text { exceptionalism/ } \\
\text { problems }\end{array}$ \\
\hline Japan & Euro & $\begin{array}{l}\text { EU integra- } \\
\text { tion }\end{array}$ & $\begin{array}{l}\text { individual } \\
\text { countries }\end{array}$ & $\begin{array}{l}\text { disparities/ } \\
\text { unfairness }\end{array}$ \\
\hline
\end{tabular}

The themes of EU integration and common currency came among the top two responses. The EU was seen as a powerful and united entity, but still distant from both Japan and Korea. The Korean responses indicated that the Koreans most favoured the idea of regional integration as a means of achieving peace and stability. The Japanese respondents, in comparison, were more prone to point out that the EU is still made up of different nation-states. (It is important to notice that the Japanese press featured the EU states as the most visible actors in the EU context, reporting them more frequently than EU institutions or officials). In Japan and Korea, the EU was often associated with its three most influ- 
ential countries - Germany, the UK and France (a parallel with media portrayals of the EU was noted here again). Responses in both countries were characterized by a very low share of negative associations possibly reflecting predominantly neutral media coverage, but also probably following the cultural notion of 'politeness' peculiar to Asian societies (discussed above), which might rule respondents to present things in a slightly better light in order 'not to offend'.

\section{Discussion}

While this study could be argued to present only a snapshot of the EU's imagery in Japan and Korea (the state of perceptions in 2006, the year of the sixth ASEM summit), this study is the first ever to look at the media representations and public images of the EU on a highly systematic, intentionally comparative and empirically comprehensive manner allowing departure from anecdotal evidence. Being a part of a larger transnational project involving twelve Asian countries and supported by the Asia-Europe Foundation (ASEF), in the future the study of EU external perceptions in Asia is planned to be extended to include all Asian ASEM countries in the region, as well as a second wave of measurements, allowing a longitudinal perspective on the imagery in question. Future studies will also allow investigating and commenting on contrasting images produced by EU member countries vs. the EU.

As the first of its kind of study in Japan and Korea, this research identified that the EU was an independently recognized political concept (despite its constantly evolving status). It was also found that the media and the general public imagery of the EU, as an emerging concept, was centred on rather specific contents, for instance, the interest in trade (consider recognition of the EU's influences in the WTO process in Japan or EU-Korea FTA importance in Korea) and business/financial activities of the Union (the euro as a potent symbol of political and economic integration). In its unity, the EU-27 was recognized as an environmental actor of growing importance (consider recognition of its role in the Kyoto protocol). Finally, its roles as a unified international political and social actor entered the list of perceptions on media and public agendas in Japan and Korea, namely the EU's international dealings with the US, China and the Middle East, as well as the EU's reputation as a hub for education and research. An ongoing analysis of the imagery will allow us to judge if these topics were only current then, or if they carry more stable and long-term implications. 
The most typical images of the EU in Japan and Korea featured contrasting themes of the EU as a synonym of an ongoing integration process vis-à-vis the EU as an entity comprised of individual member states. This ambivalent portrayal was highly expected taking into account the indefinite identity of the EU that is a polity which will never be a federal state, but which has become more than just a mere sum of its parts. On the one hand, the EU became a global 'poster child' of economic regional integration, a viable reference point for other regional organizations and even an aspiration for a possible North East Asian sub-regional grouping currently debated by political scholars and practitioners. On the other hand, the perception of European integration registered that for the public outside EU borders, the line between individual EU member states and the EU is not necessarily clear. A peculiar external presence of the Union-sometimes described as a cacophony of European voices in the international arena coming from national and supranational actors - could be yet another reason for this confusion. It is believed that a choir of disjointed voices contributes to relatively scant and diverse images of the EU that are being currently formed and cemented in Japan and Korea.

The economic references dominated Korea's and Japan's current visions of the EU in contrast to the perceptions of other global roles. EU political roles were gradually more visible, yet overshadowed by the presence and actions of individual member states. The visions of the EU as a social actor were minimal, the reflections of the EU's environmental actions have only begun to surface and the images of the EU as a developmental 'champion' and international human rights advocate remained largely invisible. One of the important findings was that the EU's status of an economic 'giant' in the region and its key importance for the economic well-being of Japan and Korea did not translate into perceived importance of the EU among the general public of the two countries in this study. The general public and reputable media in the two economic 'heavyweights' in Asia identify the shifting priories in the geopolitics of their region, and the EU is not seen as the first choice in terms of its importance for their respective countries - neither at present, nor in the future. It is suggested that historical peculiarities of both Japanese and Korean societies - namely both being insulated from Europe - make it difficult for the EU to infiltrate the two Asian societies at present further than a fairly superficial, business-like relationship. Low perceived importance of the EU among Japan's and Korea's general public is arguably further reinforced by the feelings of geographical 
and cultural distance between the two regions. Image ranking revealed that the 'top' positions in the public perceptions were given to the US and China. The general public negatively compared EU present-day importance to the one projected of the US, and in evaluating the EU's future importance, the general public picked China over the EU.

Lessons can be drawn from such comparisons. The findings seem to echo a recent statement by Joschka Fischer (cited in Mahony 2007), who noted that beyond its borders, the EU is at risk of 'increasingly fading away' and in jeopardy of being overlooked in favour of other 'superpowers-in-waiting', China in particular. In such circumstances, the EU could increase its presence in Japan and Korea via raising the Union's profile in local media and among the members of the general public. In the former case, a coherent revision of the EU's strategies in dealing with the systems of international political communication is necessary in order to make the Union's media presence more visible and locally-involved. In the latter case, more personal experiences of the Union among the international public may lead to a more informed and weighted perception of the EU. Both areas are key in the EU's public diplomacy effort, which, according to the European Commission (2007) 'seeks to promote EU interests by understanding, informing and influencing. It means clearly explaining the EU's goals, policies and activities and fostering understanding of these goals'.

Realistically, promotion of the Union's media profile and personal exposure to the EU among the general public in Japan and Korea is easier said than done. In its current dialogues with Asia, the EU places a major emphasis on its relations with China (sometime at the expense of other Asian partners) and continues to provide significant amounts of developmental aid to the countries in South and South East Asia (not to mention military missions in the region). Even cultural exchanges, a highly sought after type of interaction with Europe in both Japan and Korea, are atomized and sporadic on behalf of the EU. Initiated by many actors in the EU's external relations, cultural contacts remain unconcerted and do not necessarily result in raising the EU's profile outside its borders. Korski (2008), for example, mentioned that activities of the member states' cultural institutions - the likes of the British Council, Alliance Française, Goethe Instititut, etc. - do not automatically include an 'EU message'. At the same time, there is no 'EU Institute' in place to promote the EU's cultural diplomacy. Moreover, the Union's pubic diplomacy efforts, once described by Fiske de Gouveia and Plumridge (2005) as a 'Cinderella' in EU policy-making, are highly under-budgeted. Accord- 
ing to Korski (2008), DG RELEX spent $€ 7$ million on communications in 2005 through its bilateral delegations; a small figure if compared to the British Council's $£ 551$ million annual turnover.

This paper's main argument is that if the EU is serious about succeeding in its public diplomacy worldwide, the EU should develop its own 'branding' and 'marketing' strategies toward the foreign public. For outsiders, the EU is sometimes seen as lagging behind in its public diplomacy efforts compared to other assertive players in the region, especially the US. Commenting on how the EU's post-tsunami aid was totally ignored by the Thai news, a local television newsmaker stated,

I think the EU lost the opportunity to publicise themselves. The US concerns a lot about their image. The EU, on the other hand, won't spend a lot of money for something extravagant like that. They don't really care about international image-construction. They think they already look good because they are developed countries. It's like they don't care what other countries may think, for they know they've got something good. They don't realise that sometimes PR is necessary in image-building, otherwise your image in the international arena will decline.

With the Union experiencing regular 'identity crises', which often display the EU to the global community as being neither stable nor monolithic, establishing a long-term, stable and comprehensive positive image of the EU will take time and resources. The findings of this study echo an argument by Tsuruoka (2008: 15): 'much of EU's attention has been paid to "product development" while ignoring the "market research". Now it is time to analyse the market outside the Union in which EU foreign policy is consumed.' In this context, external images of the EU could be described, using the concepts of economics, as 'intangibles' (Zambon 2005), immaterial assets building the substantial foundation of the institution. Mismeasured or undermeasured intangibles are argued to have serious policy consequences. An imperfect set of indicators may result in inappropriate policy, misallocation of resources, and under- or over-evaluation of the organization's performance. And even though images and perceptions are immaterial assets, they may result in serious material consequences. As Movahedi (1985) states, 'international perceptions and attribution operate post hoc as a justificatory mechanism for the rationalization of many foreign policy decisions or actions taken in favor of or against another nation.' 
Natalia Chaban has a PhD, is senior lecturer and Deputy Director at National Centre for Research on Europe, University of Canterbury, New Zealand. (natalia.chaban@canterbury.ac.nz)

Christian Elias Schneider is a recent graduate of the NCRE BA (Honours) programme, Multidisciplinary Department of European Studies. (schneider82@gmail.com)

Richard Malthus is a recent graduate of the NCRE BA (Honours) programme, National Centre for Research on Europe, University of Canterbury. (rjmalthus@gmail.com)

\section{NOTES}

1 The survey took place in Brazil, China, Japan, Russia, India, the US, France, Germany and the UK.

2 See also materials of the international conference 'EU-Asia Relations: A Critical Review', CERC, The University of Melbourne, 27-28 March 2008.

3 It is worth noting that the US's reputation has been somewhat deteriorating in South Korean society (see Kim, S. 2002. 'Anti-Americanism in Korea'. The Washington Quarterly: 109-22; Cumings, B. 2004. 'Anti-Americanism in the Republic of Korea'. The Korea Economic Institute Joint U.S.-Korea Academic Studies 14: 205-29; Shin, G., and P. Y. Chang 2004. 'The Politics of Nationalism in U.S.-Korean Relations'. Asian Perspective 28(4): 119-45; Yoo, C. Y. 2005. 'Anti-American, Pro-Chinese Sentiment in South Korea'. East Asia 22(1): 18-32. The main argued reason for that change is a diminishing of the historical attachment to the US due to changing demographics and their considerably differing perceptions of the North Korean issue.

4 Asian countries of Japan, South Korea, China (mainland, SAR Hong Kong and SAR Macau), India, Singapore, Thailand, Indonesia, Vietnam, Malaysia and the Philippines; Australasian countries of Australia and New Zealand; and Pacific countries of Fiji, Papua New Guinea, the Solomon Islands, the Cook Islands and Samoa.

5 Neuman et al. deliberately refrained from using the term 'theory', using instead the term 'paradigm'.

6 ASEF Initiative 'European Studies in Asia', http:/ / esia.asef.org/.

7 Additionally, Korea is the country with the world's highest broadband connectivity (Thussu 2007: 161).

8 Amsterdam School of Communication Research (among its many studies there are de Vreese, Claes, Susan Banducci, Holli Semetko and Hajo Boomgaarden 2006. 'The News Coverage of the 2004 European Parlimentary Election Campaign in 25 countries'. European Union Politics 7(4): 477-504; Vreese de, Claes 2003. Framing Europe: Television News and European Integration. Amsterdam: Aksant; Peter, Jochen, Holli Semetko and Claes de Vreese, 2003. 'EU Politics on Television News', European Union Politics 4(3): 305-27; Semetko, Holli and Patti Valkenburg 2000. 'Framing European Politics: A Content Analysis of Press and Television News', Journal of Communication 50(2): 93-109).

9 The Yomiuri Shimbun has news bureaus in the European cities of London, Paris, Berlin, Frankfurt, Brussels, Rome, Vienna, Prague; The Nikkei has news bureaus in London, Paris, Berlin, Frankfurt, Brussels, Milan, Vienna, Budapest, Warsaw; The 
Chosun Daily has bureaus in London, Frankfurt, Paris and Moscow. This wide net of news bureaus in Europe is very different from other Asian countries in the study of the EU perceptions in the Asia-Pacific.

10 The Japanese Times has no correspondents posted to Europe.

11 In the case of the Korean survey.

12 In the case of the Japanese survey.

\section{REFERENCES}

Adams, William C. 1987. 'Mass Media and Public Opinion about Foreign Affairs: A Typology of News Dynamics'. Political Communication and Persuasion 4(4): 263-78.

Albritton, Robert B. and Jarol B. Manheim 1983. 'News of Rhodesia: The Impact of a Public Relations Campaign'. Journalism Quarterly 60(6): 622-28.

Anderson, P. and A. Weymouth 1999. Insulting the Public: The British Press and the European Union. New York: Longman.

Ball-Rokeach, Sandra J. and Melvin L.L. DeFleur 1976. 'A Dependency Model of Mass Media Effect'. Communication Research 1: 3-21.

Bell, Lydia 2004. 'Push More Pens - Europe - A Worldwide Special Report - The Bureaucracy'. The Australian, 3 May, T11.

Bertelsmann Stiftung 2006. World Powers in the $21^{\text {st }}$ Century. Available from www.cap. lmu.de/download/2006/2006_GPC_Survey_Results.pdf.

Boxer, C. R. and M. Moscato 1979. Papers on Portuguese, Dutch, and Jesuit Influences in 16th- and 17th- Century Japan: Writings of Charles Ralph Boxer. Washington D.C.: University Publications of America.

Brenner, Neil 1999. 'Beyond State-Centrism? Space, Territoriality and GeoFigureic Scale in Globalization Studies'. Theory and Society 28(1): 39-78.

Brewer, Paul R., Joseph Graf and Lars Willnat 2003. 'Priming or Framing: Media Influence on Attitudes toward Foreign Countries', Gazette 65(6): 493-508

Bridges, B. 1999. Europe and the Challenge of the Asia Pacific: Change, Continuity and Crisis. Cheltenham, UK: Edward Elgar.

Castells, M. 1996. The Information Age-Economy, Society and Culture: The Rise of the Network Society. Vol.1. Oxford: Blackwell.

Cederman, Lars-Erik (ed.) 2001. Constructing Europe's Identity: The External Dimension. Boulder, CO: Lynne Rienner Publishers.

Chaban Natalia, 2008. The EU through the Eyes of Asia's National Elites: Views from Japan, South Korea, Mainland China, SAR Hong Kong, Singapore and Thailand. Paper presented at the conference "EU-Asia Relations: A Critical Review", CERC, University of Melbourne, 27-28 March 2008.

- and M. Holland (eds) 2005. The EU through the Eyes of the Asia-Pacific: Public Perceptions and Media Representations. NCRE Research Series 4. University of Canterbury: NCRE.

- and Marco Kauffmann 2007. 'East is East, and West is West?: Survey of EU Images in Japan's Public Discourses'. European Foreign Affairs Review 12(3): 363-84.

- and M. Holland (eds) 2008. The European Union and the Asia-Pacific: Media, Public and Elite Perceptions of the EU. London: Routledge.

CIA, The World Fact Book (online). Available from: https://www.cia.gov/library/publications/the-world-factbook/.

Cohen, B. 1963. The Press and Foreign Policy. Princeton: Princeton University Press.

-1965. 'Mass Communication and Foreign Policy'. In J. N. Rosenau (ed.). Domestic Sources of Foreign Policy. New York: The Free Press 1965: 195-212. 
Davison, W. Phillips, D. P. Shanor and F. T. Yu 1980. News from Abroad and the Foreign Policy: Headline Series No. 250. New York: Foreign Policy Association.

Dent, C. 1999. The European Union and East Asia: An Economic Relationship. London, New York: Routledge.

Duff, Andrew 2006. 'Plan B: How to Rescue the European Constitution'. Notre Europe: Etudes and Recherchers 52 (online). Available from: http://www.notre-europe.eu/ uploads/tx_publication/Etud52-en_01.pdf.

EC Delegation to Japan (online). Available from: http:/ / ec.europa.eu/trade/issues/ bilateral/countries/japan/index_en.htm.

EC Delegation to the Republic of Korea (online). Available from: http://www.delkor. ec.europa.eu/home/relations/rokrelations/rokrelations.html.

Edelstein, Alex S. 1993. 'Thinking about the Criterion Variable in Agenda-Setting Research'. Journal of Communication 43(2): 85-99.

Elgström, Ole 2006. 'Leader or Foot-Dragger? Perceptions of the European Union in Multilateral International Negotiations'. Report 1 (online). Available from: www.sieps. se/publ/rapporter/bilagorf2006 I.pdf.

Elgström, O. and M. Smith (eds) 2006. The European Union's Roles in International Politics: Concepts and Analysis. London: Routledge.

Entman, Robert 1993. 'Framing: Toward Clarification of a Fractured Paradigm'. Journal of Communication 43(4): 51-58.

EuropeAid 2003. 'Survey Analysis of EU Perceptions in South East Asia'. Framework Contract AMS/451-Lot 7.

EuropeAid Final Report 2007. 'Perceptions of the EU's Role in South East Asia', Framework Contract EuropeAid/123314/C/SER/multi, Lot n4, 2007/144031.

European Commission, Communication 'Towards a New Asia Strategy', COM(94) 314, 13 July 1994.

European Commission, DG RELEX, The EU's 50th Anniversary Celebrations around the World: A Glance at EU Public Diplomacy at Work (online). Available from: europa. eu/50/around_world/images/2007_50th_anniv_broch_en.pdf.

European Commission, External Relations (online). Available from: http:/ / ec.europa. eu/external_relations/asia/index.htm.

Ferrero-Waldner, Benita 2007. The European Union and the World: a Hard Look at Soft Power. SPEECH/07/576, 24 Sept. 2007, New York, Columbia University.

Fiske de Gouveia, Phillip and Hester Plumridge 2005. European Infopolitik: Developing EU Pubic Strategy (online). London: The Foreign Policy Centre. Available from: http://fpc.org.uk/fsblob/657.pdf.

Fournier, Patrick, André Blais, Richard Nadeau, Elisabeth Gidengil, \& Neil Nevitte 2003. 'Issue Importance and Performance Voting'. Political Behaviour 25(1): 51-67.

Fukasaku, K., K.Fukunari and U. Shujiro (eds) 1998. Asia \& Europe: Beyond Competing Regionalism. Sussex: Academic Press.

Galtung, Johan and Mari Holmboe Ruge 1965. 'The Structure of Foreign News', Journal of Peace Research 2(1): 64-91.

GARNET 2007. Lucarelli, Sonia (ed). 'The External Image of the European Union' (online). Working Paper No. 17. Available from: http://www.garnet-eu.org/index. php?id=27, also reported in Lucarelli, Sonia (ed.) 2007. Special Issue 'Beyond Self-Perception: The Other's View of the European Union'. European Foreign Affairs Review 12(3).

GARNET 2009. Lucarelli, Sonia and Lorenzo Fioramonti (ed.). 'Research Report: The External Image of the European Union - Phase Two'. (on line). Working Paper No. 62. Available from: http://www.garnet-eu.org/index.php?id=27

Gavin, Neil 2000. 'Imagining Europe: Political Identity and British Television Cover- 
age of the European Economy'. British Journal of Politics and International Relations 2(3): 352-73.

Gilson, Julie (ed.) 2002. Asia Meets Europe: Inter-Regionalism and the Asia-Europe Meeting. Cheltenham, UK: Edward Elgar.

Goodman, G. K. 1986. Japan: the Dutch Experience. London: Athlone.

Hara, Takemichi 1998. 'Korea, China, and Western Barbarians: diplomacy in early nineteenth-century Korea'. Modern Asian Studies 32(2): 389-430.

Hastings, Adi and Paul Manning 2004. 'Introduction: Acts of Alterity'. Language and Communication 24(4): 291-311.

Hendry, Joy 1989. 'To Wrap or Not to Wrap: Politeness and Penetration in EthnoFigureic Inquiry'. Man 24(4): 620-35.

Hirst, P. and G. Thompson 1996. Globalization in Question, The International Economy and the Possibilities of Governance. Cambridge, UK: Polity Press.

Holland, Martin 1995. European Union Common Foreign Policy: From EPC to CFSP Joint Action and South Africa. London: MacMillan Publishers.

-1999. 'The Common Foreign and Security Policy'. In Cram, Laura, Desmond Dinan and Neill Nugent (eds). Developments in the European Union: London: Macmillan 1999: 230-46.

-2005. Common Foreign and Security Po1icy: The First Ten Years. London: Continuum.

- Peter Ryan, Alojzy Nowak and Natalia Chaban (eds) 2007. The EU through the Eyes of Asia: Media, Public and Elite Perceptions in China, Japan, Korea, Singapore and Thailand. Singapore-Warsaw: University of Warsaw.

Huntington, Samuel P. 'The Clash of Civilizations'. Foreign Affairs (online) 72(3). Available from: www.AllanNoble.net/articles_by_samuel_huntington.htm.

IMF 2007. 'The World Economic Outlook Database' (online). October. Available from: http:/ / www.imf.org/external/pubs/ft/weo/2007/02/weodata/index.aspx.

Jackson, J. 2004. The Red-Hair People of Deshima: Dutch Traders and Their Impact on Japan (online). Available from: http://filebox.vt.edu/users/jojacks2/words/redhairs. htm.

Jaffe, E. D. and I. D. Nebenzahl 2001. National Image and Competitive Advantage. Copenhagen: Copenhagen Business School Press.

Katzenstein, Peter J. 2005. A World of Regions: Asia and Europe in the American Imperium. Ithaca: Cornell University Press.

Kennedy, Liam and Scott Lucas 2005. 'Enduring Freedom: Public Diplomacy and US Foreign Policy'. Pubic Diplomacy and US Foreign Policy 57(2): 309-33.

Kevin, D. 2003. Europe in the Media. London: Lawrence Erlbaum Associates.

Kipling, Rudyard. The Ballad of East and West.

Korski, Daniel 2008. 'Making Europe's Voice Louder' (online). European Council on Foreign Relations. Available from: www.ecfr.eu/content/entry/commentary_making_europes_voice_louder.

Larson, J. F. 1984. Television's Window on the World: International Affairs Coverage on the U.S. Networks. Norwood, NJ: Ablex Publishing.

-1979. 'International Affairs Coverage on U.S. Network Television'. Journal of Commmunication 29(2): 136-147.

Lisbonne-de Vergeron, K. 2007. Contemporary Chinese Views of Europe. London: Chatham House.

-2006. Contemporary Indian Views of Europe. London: Chatham House.

Livingston, Steven. 1997. Clarifying the CNN effect: an examination of media effects according to type of military intervention (online). Available from: http:/ / www.ksg. harvard.edu/presspol/Research_Publications/Papers/Research_Papers/R18.pdf. Lucarelli, Sonia 2006. 'Interpreted Values: A Normative Reading of EU Role Concep- 
tions \& Performance'. In O. Elgström and M. Smith (eds) The European Union's Roles in International Politics: Concepts and Analysis. London: Routledge.

-2007. 'European political identity and the others' image of the EU: reflections on an unexplored relationship'. Paper presented at GARNET-JERP 5.2.1 Final Conference The Europeans. The European Union in Search of Political Identity and Legitimacy, 25-26 May 2007, Florence.

- and I. Manners (eds) 2006. Values and Principles in European Union Foreign Policy. London: Routledge.

Lynch, David 2005. 'Communicating Europe to the World: What Public Diplomacy for the EU?'. European Policy Center Working Paper No.2 (online). Available from: epc. eu/TEWN/pdf/251965810_EPC\%2021.pdf.

Mahony, Honor 2007. 'Europe is Increasingly Fading Away'. Eurobserver, 30 March.

Maitland, D. and Y. Hu 1998. Europe and Emerging Asia. London: Federal Trust for Education and Research.

Manheim, Jarol B. and Robert B. Albritton 1984. 'Changing National Images: International Public Relations and Media Agenda Setting'. American Political Science Review 78: 641-57.

Manners, Ian and Richard Whitman 1998. 'Towards Identifying the International Identity of the European Union: A Framework for Analysis of the EU's Network of Relationships'. European Integration 21(2): 231-249.

McCombs, Maxwell and Donald Shaw 1972. 'The Agenda-Setting Function of Mass Media'. Public Opinion Quarterly 36: 176-185.

Moisy, Claude 1997. 'Myths of the Global Information Village'. Foreign Policy (online) 107. Available from: http://search.epnet.com.ezproxy.canterbury.ac.nz/login. aspx?direct $=$ true\&db=anh\&an=9708190354.

Morgan, N., A. Pritchard and R. Pride (eds.) 2004. Destination Branding: Creating the Unique Destination Proposition. London: Elsevier Butterworth Heinmann.

Movahedi, Siamak 1985. 'The Social Psychology of Foreign Policy and the Politics of International Images'. Human Affairs 8(19): 18-37.

Murray, Philomena 2002a. 'Australian Voices: Some Elite Reflections on the European Union'. CESAA Review (online) 29: 5-18. Available from: http://www.cesaa.org. $\mathrm{au} /$ publications.htm.

-2002b. 'What Australians think about the EU: Elite Perceptions and the Current Context'. Paper presented at the Conference on the EU in International Affairs, NEC, July 2002, Canberra.

-1999. 'Australian Perspectives on the European Union'. European Information 8: 2-5.

Neuman, W. R., M. R. Just and A. N. Cligler 1992. Common Knowledge: News and Construction of Political Meaning. Chicago and London: The University of Chicago Press.

Neves, M. S. and B. Bridges (eds) 2000. Europe, China and the Two SARs: Towards a New Era. London: Macmillan Press.

Norris, P., M. Kern and M. Just 2003. 'Framing Terrorism'. In P. Norris, M. Kern and M. Just (eds), Framing Terrorism: The News Media, the Government and the Public, New York: Routledge.

OECD (online). Available from: http://www.oecd.org/about/0,2337,en_2649_201185_ 1_1_1_1_1,00.html.

Ooi, C.-S. 2004. 'The poetics and politics of destination branding: Denmark'. Scandinavian Journal of Hospitality and Tourism 4(2): 107-128.

Ortega, M. (ed.) 2004. 'Global Views on the European Union'. Chaillot Paper (online), 72. Paris: EU-ISS. Available from: www.iss-eu.org/chaillotJchai72.pdf..

Palmgreen, Philip and Peter Clark 1977. 'Agenda Setting with Local and National Issues'. Communication Research 4(4): 435-52. 
Perry, David K. 1985. 'The Mass Media and Inference About Other Nations'. Communication Research 12(4): 595-614.

-1990. 'News Reading, Knowledge About, and Attitudes toward Foreign Countries'. Journalism Quarterly 67(2): 353-8.

-1987. 'The Image Gap: How International News Affects Perceptions of Nations'. Journalism Quarterly 64(2-3): 416-21.

Peter, Jochen, Holli Semetko and Claes de Vreese 2003. 'EU Politics on Television News', European Union Politics 4(3): 305-27.

Petrella, Riccardo 1996. 'Globalization and Internationalization: The Dynamics of the Emerging World Order'. In R. Boyer and D. Drache (eds). States against Market: The Limits of Globalization. NY, London: Routledge: 62-83.

Preston, P. W. and J. Gilson (eds) 2001. The European Union and East Asia: Interregional Linkages in a Changing Global System. Cheltenham, UK: Edward Elgar.

Protess, D. L. and M. McCombs 1991. Agenda Setting. Readings on Media, Public Opinion, and Policy Making. Hillsdale, NJ: Lawrence Erlbaum.

Roberts, J. M. 1999. Twentieth Century: The History of the World, 1901-2000. NY: Viking, Penguin.

Roessler, Patrick 1999. 'The Individual Agenda-Designing Process: How Interpersonal Communication, Egocentric Nertworks, and Mass Media Shape the Perception of Political Issues by Individuals' '. Communication Research 26(6); 666-700.

Rubin, B. 1979. How Others Report Us: America in the Foreign Press. Beverly Hills, London: Sage Publications.

Sasae, Kenichiro 1994. 'Rethinking Japan-US Relations'. Adelphi Paper 292. London: Brassey's for IISS.

Sassen, S. 1991. The Global City. Princeton: Princeton University Press.

Scheufele, Dietram A. 1999. 'Framing as a Theory of Media Effects'. Journal of Communication 49(1): 103-22.

Schmitter, Philippe C. 1996. 'Examining the Present Euro-Polity with the Help of Past Theories'. In G. Marks, F. Scharpf, P. Schmitter and W. Streeck. (eds), Governance in the European Union. London: Sage.

Schulz, Winfried 2001. 'Foreign News in Leading Newspapers of Western and Post-Communist Countries'. Paper presented at the $51^{\text {st }}$ Annual Conference of the International Communication Association. 24-28 May, Washington D.C.

Shambaugh, D., E. Sandschneider and H. Zhou (eds) 2007. China-Europe Relations: Perceptions, Policies and Prospects. London: Routledge.

Shin, Doh Chull and Jaechul Lee 2006. 'The Korea Democracy Barometer Surveys: Unraveling the Cultural and Institutional Dynamics of Democratization, 1997-2004'. Korea Observer 37(2): 237-75.

Sjursen, Helene (ed.) 2006. 'What Kind of Power? European Foreign Policy in Perspective' Journal of European Public Policy (special issue) 13(2): 169-81.

Smith, A. 1980. Geo-politics of Information: How Western Culture Dominates the World. New York: Oxford University Press.

Smith, H. 2002. European Union Foreign Policy: What It Is and What It Does. London and Sterling, VA: Pluto Press.

Smith, Karen E. 2002. 'Conceptualizing the EU's International Identity: Sui Generis or Following the Latest Trends?'. Paper presented at the First Pan-European Conference on European Union Politics. 26-28 Sept. 2002, Bordeaux.

Soroka, S. N. 2002. Agenda-Setting Dynamics in Canada. Vancouver: UBC Press.

Spondenberg, Helena 2007. 'Europeans Want the EU to Take More Global Responsibility', Euobserver, 9 Sept .

Stempel, Guido and Thomas Hargrove 1996. 'Mass Media Audiences in a Changing 
Media Environment'. Journalism and Mass Communication 73(3): 549-58.

Strange, R., J. Slater and C. Molteni (eds) 2000. The European Union and ASEAN: Trade and Investment Issues. London: Macmillan Press.

Stråth, Bo 2002. 'A European Identity: To the Historical Limits of a Concept'. European Journal of Social Theory 5(4): 387-401.

The Economist. 2008. 'Japain'. February 23-29.

Thussu, D. K. 2007. News as Entertainment: The Rise of Global Infotainment. Los Angeles: Sage Publications.

Trenz, Hans-Joerg 2004. 'Media Coverage of European Governance: Exploring the European Public Sphere in National Quality Newspapers'. European Journal of Communication 19(3): 291-319.

Tsuruoka, Michito 2006. 'How External Perspectives of the European Union are Shaped: Endogenous and Exogenous Sources'. Paper prepared for the 20th World Congress of the International Political Science Association (IPSA), 9-13 July 2006, Fukuoka.

-2008. 'How External Perceptions of the EU are Shaped: Endogenous and Exogenous Sources'. Paper at the The EU in International Affairs Conference, Brussels, 24-26 April 2008.

Twigg, Stephen 2005. 'Preface' in Philip Fiske de Gouveia and Hester Plumridge. European Infopolitik: Developing EU Pubic Strategy. London: The Foreign Policy Centre 2005: VI-VII.

US German Marshall Fund 2007. EUobserver (online). Available from: http://euobserver.com/9/24717/?print=1.

van Dijk, T. A. 1998. Ideology: A Multidisciplinary Approach. London: Sage.

van Ginneken, J. 1998. Understanding Global News. Thousand Oaks, CA: Sage.

Vucheva, Elitsa 2007. 'EU global image improving, US fading'. EUobserver 13 Dec.

Walker, Martin 2000/01. 'Europe: Superstate or Superpower?'. World Policy Journal (online)17(4). Available from: http://worldpolicy.org/journal/sum00-4.html\#2.

Wallström, Margot 2005. 'Communicating a Europe in Stormy Waters: Plan D'. Paper at European Voice conference 'Simplifying Europe', 28 June 2005, Brussels, SPEECH/05/396.

Wodak, Ruth 1987. '"And Where Is the Lebanon?" A Socio-Psycholinguistic Investigation of Comprehension and Intelligibility of News'. Text 7(4): 377-410.

World Association of Newspapers (online). Available from: http://www.wan-press. org/article2825.html?var_recherche=chosun.

Zambon, Stefano 2005. 'Visualizing Intangibles as Company Drovers of Innovation and Growth Some Recent European Developments'. Presentation at the NCRE Research Round table Seminar, University of Canterbury, 22 July. 